serum lithium concentrations in patients taking the drug and indicates that, although often reversible, metabolic disturbances may persist for more than two years after treatment is stopped.

We thank Dr D Pariente for referring the patient and dealing with the psychiatric problems, and Professor J L H O'Riordan, Middlesex Hospital, for advice on the endocrinological aspects of the case.

1 Neil Johnson F, ed. Handbook of lithium therapy. New York: MTP Press Ltd,

1980.
Ananth J, Dubin SE. Lithium and symptomatic hyperparathyroidism. F R Soc Med $1983 ; 76: 1026-9$.

3 Rabin E, Garston R, Weir R, Posen G. Persistent nephrogenic diabetes insipidus associated with long-term lithium carbonate treatment. Can Med Assoc $\mathcal{F}$ $1979 ; 121: 194-8$

(Accepted 20 November 1984)

Department of Medicine, Edgware General Hospital, Edgware, Middlesex HA8 0AD

STUART R CAIRNS, MD, MRCP, senior medical registrar

ROGER WOLMAN, BSC, MRCP, senior house officer

JEROME G LEWIS, MD, FRCP, consultant physician

Department of Medicine, Middlesex Hospital, London W1

RAJESH 'THAKKER, MA, MRCP, medical registrar

Correspondence to: Dr S R Cairns.

\section{Severe leucopenia in fatal lithium poisoning}

Lithium carbonate is commonly used to treat manic depressive psychosis. ${ }^{1}$ Numerous adverse effects (some related to dose) have been described, and it is important that plasma lithium concentrations are monitored regularly so that they may be maintained within the therapeutic range of $0.6-1.2 \mathrm{mmol} / 1(0 \cdot 42-0.83 \mathrm{mg} / 100 \mathrm{ml}){ }^{1}$ Gastrointestinal, endocrine, neurological, and renal side effects are well recognised, ${ }^{1}$ and haematological abnormalities have been less commonly described. ${ }^{-5}$ Severe toxicity may occur with plasma lithium concentrations over $2 \cdot 0-2.5 \mathrm{mmol} / 1(1 \cdot 4-1.7 \mathrm{mg} / 100 \mathrm{ml})$ and is potentially lethal. ${ }^{1}$ Therapeutic efforts to reduce plasma lithium concentrations may be hampered by continued absorption from sustained release preparations. ${ }^{1}$

We describe a fatal case of self poisoning with lithium carbonate that resulted in severe leucopenia before death.

\section{Case report}

A 49 year old man with a long history of depression was admitted as an emergency in a stuporous condition (day 1). His general health had been good, and his only regular medication was lithium carbonate (sustained release) $800 \mathrm{mg}$ a day, although on occasions he had received chlorpromazine, thioridazine, flupenthixol, and benzodiazepines without ill effect. He had been found unconscious and was estimated to have ingested more than 30 lithium carbonate $400 \mathrm{mg}$ tablets. He had also taken an undetermined number of tablets of chlorpromazine $25 \mathrm{mg}$, flurazepam $1 \mathrm{mg}$, and temazepam $10 \mathrm{mg}$, but there had been no more than three tablets in each container before overdosage.

On examination he was polyuric, haemodynamically stable, and breathing spontaneously. Serum lithium concentration was $3.32 \mathrm{mmol} / \mathrm{l}(2.3 \mathrm{mg} / 100 \mathrm{ml})$ (no other drugs detectable), haemoglobin concentration $14 \cdot 1 \mathrm{~g} / \mathrm{dl}$, red cell count $4.99 \times 10^{12} / 1$, white cell count $10.0 \times 10^{9} / 1$, and platelets $283 \times 10^{9} / 1$. Gastric lavage was performed, intravenous fluids started, and $50 \mathrm{ml}$ lactulose given orally. No other drugs were administered. Five hours later the serum lithium concentration reached $5.54 \mathrm{mmol} / \mathrm{l}(3.8 \mathrm{mg} / 100 \mathrm{ml}$ ) (haemoglobin concentration $17.5 \mathrm{~g} / \mathrm{dl}$, red cell $\mathrm{c}$ unt $5.58 \times 10^{12} / 1$, white cells $11.2 \times 10^{9} / 1$, platelets $\left.111 \times 10^{9} / 1\right)$ and peritoneal dialysis was started. On the morning of day 2 the serum lithium concentration reached $5.8 \mathrm{mmol} / 1(4.0 \mathrm{mg} / 100 \mathrm{ml})$ while the white cell count had fallen to $1.4 \times 10^{9} / 1$ with an unremarkable differential count $(74 \%$ neutrophils, $22 \%$ lymphocytes, $2 \%$ eosinophils, $2 \%$ monocytes, no basophils). The red cell count was $4.33 \times 10^{12} / 1$, haemoglobin concentration $12.6 \mathrm{~g} / \mathrm{dl}$, and platelets $242 \times 10^{9} / 1$.

He subsequently became hypotensive and developed type 1 respiratory failure, although there was no suggestion of any infective process at any site and the temperature remained between $35 \mathrm{C}$ and $37^{\circ} \mathrm{C}$. Positive end expiratory pressure ventilation and intravenous dopamine were started. Peritoneal dialysis was continued. By day 3 serum lithium concentration had fallen to $3.9 \mathrm{mmol} / 1(2.7 \mathrm{mg} / 100 \mathrm{ml})$ but the white cell count was $0.2 \times 10^{9} / 1$ (haemoglobin concentration $11.5 \mathrm{~g} / \mathrm{dl}$, red cells $3.97 \times 10^{12} / 1$, platelets $111 \times$ $10^{9} / 1$ ). Shortly after, he had an asystolic cardiac arrest and attempts at resuscitation were unsuccessful.

\section{Comment}

The major point of interest was the development of pronounced leucopenia (without appreciable changes in circulating red cell and platelet counts) associated with an acute rise in plasma lithium concentrations, which had previously been within the therapeutic range. This does not appear to have been described previously. Conversely, circulatory failure is well recognised.

Haematological abnormalities have been described in association with long term lithium treatment. A reversible increase in circulating leucocytes may occur, and lithium might be of value in treating neutropenia induced by chemotherapy. ${ }^{2}$ Associations with leukaemic conditions and megaloblastic anaemia have also been noted. ${ }^{34}$ Hussain et al reported on a patient maintained on imipramine and thioridazine who developed fatal aplastic anaemia 12 weeks after starting lithium $300 \mathrm{mg}$ daily; the serum lithium concentration did not exceed $0.76 \mathrm{mmol} / 1(0.53 \mathrm{mg} / 100 \mathrm{ml}) .{ }^{5}$ The exact mechanism of the rapid fall in the white cell count with a normal differential described here is unclear, but it may represent a direct toxic effect of lithium at high plasma concentrations on the circulating leucocytes. Whatever the mechanism, we would recommend close monitoring of the white cell count in all cases of lithium overdosage.

We thank Dr A I Macdougall, consultant renal physician at this hospital, for his helpful advice in the preparation of this case report.

1 British Medical Association and Pharmaceutical Society of Great Britain. British national formulary number 8 . London: British Medical Association and Pharmaceutical Society of Great Britain, 1984.

2 Stein RS, Beaman C, Ali MY, Hansen R, Jenkins JD, Jume'an HG. Lithium carbonate attenuation of chemotherapy-induced neutropenia. $N$ Engl $\mathcal{f} \mathrm{Med}$ $1977 ; 297: 430-1$

3 Lysowski J, Nasrallah HA. Lithium therapy and the risk of leukaemia. $\mathrm{Br} f$ Psychiatry 1981;139:256.

4 Prakesh R, Sethi N, Agrawal SS, Kushwaha MRS, Sethi BB. A case report of megaloblastic anaemia secondary to lithium. Am $\mathcal{F}$ Psychiatry 1981;138:849.

5 Hussain MZ, Khan AG, Chaudry ZA. Aplastic anaemia associated with lithium therapy. Can Med Assoc $\mathcal{F} 1973 ; 108: 724-8$.

(Accepted 21 November 1984)

Stobhill General Hospital, Glasgow G21 3UW

$S$ T GREEN, BSC, $M B$, senior house officer

F G DUNN, MB, MRCP, consultant cardiologist

Correspondence to: Dr Green.

\section{Inadvertent duplicate publication}

\section{Treatment of severe poisoning with slow release theophylline}

Department of Medicine, University of Vienna, A-1090 Vienna, Austria

ANTON N LAGGNER, MD

GERHARD KAIK, MD, lecturer

KURT LENZ, MD

WILFRED DRUML, MD

GUNTHER KLEINBERGER, MD, lecturer

The $B M \mathcal{F}$ regrets that the case report in the above article (19 May 1984, p 1497) was substantially the same as that published in Krankenhausarzt (1983;56:413-23). The authors inform us that it was also published in Attemwegs und Lungenkrankenheiten $(1983 ; 9: 93-8)$ and reported at a symposium in Vienna (Wiener Intensive-medizinische Tage 1983). They did not, however, tell us this when the article was submitted for publication, their article did not contain any reference to the earlier papers, and all authors signed our copyright form, which states, among other things, that "papers are accepted on condition that they have not been published by any other journal."

We regret this inadvertent duplicate publication, for which the authors hold sole responsibility, and which is in violation of our Instructions to Authors and internationally agreed guidelines. 